\title{
Are Latin American Business Groups Different? An Exploratory International Political Economy Perspective
}

\author{
Michael Carney \\ John Molson School of Business \\ Concordia University \\ Montréal, Québec, Canada \\ michael.carney@concordia.ca \\ Saul Estrin* \\ London School of Economics \\ London, United Kingdom \\ Zhixiang Liang \\ John Molson School of Business \\ Concordia University \\ Montréal, Québec, Canada \\ Daniel Shapiro \\ Beedie School of Business \\ Simon Fraser University \\ Vancouver, British Columbia, Canada
}

*Corresponding author

$13^{\text {th }}$ July 2021 


\title{
Are Latin American Business Groups different? An international political economy perspective
}

\begin{abstract}
We advance an international political economy (IPE) perspective that geo-political events can have long-lasting imprint effects on countries and their firms. We explore the idea that shared political history and geography combine to create specific structural conditions that shape the international competitiveness of all firms in the region. In particular, we consider whether the Monroe Doctrine of 1823, which asserted American influence in the Western Hemisphere, contributed to the creation of institutional structures across Latin America (LA) affecting the strategies of all firms to this day. We illustrate the IPE perspective using the example of the contemporary international competitiveness of LA business groups.
\end{abstract}

Keywords: International political economy; business groups; international competitiveness; Latin America; imprint. 


\section{INTRODUCTION}

“The Monroe Doctrine is alive and well. It's our hemisphere." (John Bolton) ${ }^{1}$

The International Business (IB) literature has extensively addressed the institutional and contextual factors determining national economic performance (Dunning, 1981; Marano, Arregle, Hitt, Spadafora, \& van Essen, 2016; Weng \& Peng, 2018; Cuervo-Cazurra, Gaur, \& Singh, 2019) and behind that, the relationship between home country-level contextual factors and the performance of multinational enterprises (MNEs) (Chan \& Pattnaik, 2021; Jackson and Deeg, 2008; Cantwell, Dunning \& Lundan, 2010; Estrin, Meyer, Nielsen, \& Nielsen, 2016; Mudambi, 2018; Cuervo-Cazurra, Luo, Ramamurti, \& Ang, 2018; Rosenbusch, Gusenbauer, Hatak, Fink \& Meyer, 2019). However, consistent with institutional analyses outside of IB (North, 1990; Acemoglu \& Robinson, 2012; Estrin, Mickiewicz, Stephan \& Wright, 2019), the analysis of the impact of context in the IB literature is typically focused on the national (country) level, with institutional, cultural and political factors considered only within or across national jurisdictions.

One potential limitation of these perspectives is that their exclusive focus on home countryspecific drivers of economic performance overlooks the potential influence of regional factors such as shared history or regional geo-politics. Framing the level of analysis at the national rather than supra-national level, for example on national institutions rather than shared geography, contrasts with some of the popular discourse, which considers broader geographic areas as groups with common determinants of economic outcomes. Examples include the analysis of geographical effects by Jared Diamond (2013) or of African economic development by Michalopoulos \& Papaioannou (2020). In addition to shared geography, countries may also be linked by shared

\footnotetext{
${ }^{1}$ Dexter Filkins, “John Bolton on the Warpath”, The New Yorker. April 2019
} 
political and historical experience. For example, Soviet influence interrupted the post-war economic development of all east-central Europe; an outcome not well explained by countryspecific factors but rather by membership in the Warsaw Pact, common to them all (Meyer, 2001; Svejnar, 2002). Even when countries are grouped into "configurations" or "varieties of capitalism" based on the similarity of national institutions (Fainshmidt, Judge, Aguilera \& Smith, 2016; Witt \& Jackson, 2016; Witt et. al. 2018), the groupings do not directly account for shared political history and geography.

In this paper, we explore an international political economy (IPE) perspective of these regional factors by evaluating how long-standing regional security arrangements influence the institutional development of associated countries and the firms within them. Based on the IPE literature (Amsden, 2001; Schneider, 2009; Strange, 1994; Stopford, Strange, \& Henley, 1991; Stubbs, 2017), we argue that shared history, politics and geography combine to create specific structural conditions that help to characterise a region's development, and in so doing, influence the international competitiveness of all of its firms. Specifically, history and geographic proximity at the regional level can combine to shape participation in international trade for an entire area. We illustrate these arguments with reference to Latin America, and impact of the US Monroe doctrine, which has been in force since 1823 and which asserted US influence over the Western Hemisphere. We argue that the Monroe Doctrine has had a long-run imprint effect (Marquis \& Tilcsik, 2013) on economic policymaking in the region resulting in a common, persistent, and negative impact on the international competitiveness of firms throughout the subcontinent. Thus, the Monroe Doctrine created power asymmetries between the United States and all the countries in Latin America, which in turn restricted each states' capacities to foster industrial development, and therefore limited the competitive capabilities and international performance of all firms. 
In exploring the relationship between regional security arrangements, domestic policymaking and the relative performance of firms in Latin America, we focus attention on business groups (BGs) (Khanna \& Yafeh, 2007; Schneider, 2009). The IPE and IB literatures have highlighted how business groups are often the preferred vehicle through which the state pursues its development policies, including in Latin America (Khanna \& Palepu, 2000; Amsden, 2001; Keister, 1998; Schneider, 2010; Lazzarini, 2015). Moreover, BGs are characterized as an 'emblematic corporate form ${ }^{2}$ in promoting industrial development in emerging economies. Since the shared history derives from an international security arrangement, the Monroe Doctrine, we use as our preferred measure of relative performance, international competitiveness (Mahmood, Zhu \& Zajac, 2011; Tan \& Meyer, 2010). In our empirical counterpart, we therefore compare the internationalization of business group affiliates in Latin America with that of business group affiliates in other developing markets. We employ data from the World Bank Enterprise Survey of emerging market firms from which we draw some 32,000 observations, to determine whether the exporting performance of group affiliates in Latin America as a region are significantly different from other developing regions, controlling for a wide variety of alternative potential explanatory factors.

We contribute to the literature in three ways. First, we contribute to the IB literature on emerging market firms by offering a broader way to evaluate their performance, consistent with the problematization approach recently adopted by Deng, Delios \& Peng (2020). In particular, our approach addresses "the neglect of other important levels and dimensions of context, such as region, society, time, space, and place" (Deng et al, 2020:52). In viewing emerging markets through the lens of IPE, we therefore respond to calls for increased attention to international

\footnotetext{
${ }^{2}$ An emblematic form refers to an organizational structure that 'fits' or is best adapted to seize the opportunities provided by local institutional environments (Boyer, 2005).
} 
politics (Phan, 2019; Casson, 2020), the geography of place and space (Iammarino \& McCann, 2013), and history (Casson, 2019; Simsek, Fox \& Heavey, 2015; Argyres, De Massis, Foss, Frattini, Jones \& Silverman, 2020). The IPE perspective offers a geopolitical understanding of how locations, in this case a set of geographically contiguous countries with a broadly shared political history, can face a similar long-term imprinting born of security arrangements, that can lead to similar institutional features and thence to firm performances. In addition, our analysis may provoke a return to relatively neglected ideas that complement the IPE approach such as the Investment Development Path (Dunning, 1981; Dunning and Narula, 1998), which emphasized the connection between inward and outward FDI over time.

Second, we contribute to the research on the internationalization and performance of business groups (BGs) around the world. While scholars have identified heterogeneity among business groups in terms of structure and performance (Yiu, Lu, Bruton \& Hoskisson, 2007; Carney, Estrin, van Essen \& Shapiro, 2017), there is an identified gap in empirical studies that compare them across countries (Aguilera, Crespi-Cladera, Infantes-Sanchez \& Pascual-Fuster, 2020). In addition, scholars often attribute this heterogeneity to country-level factors such as the quality of institutions, culture, and internal politics (Chung, 2001; Schneider 2013; Khanna \& Palepu, 2010; Gaur, Kumar \& Singh, 2014; Hu, Cui \& Aulakh, 2019). We thus contribute both by examining BGs from a broad cross-section of emerging economies, and by suggesting how IPE can contribute to the understanding of heterogeneous performance across regions.

Finally, we contribute to the increased recent interest in Multilatinas (Aguilera et al, 2018), and in particular to research on why their global presence is limited (Cuervo-Cazurra, 2016). We illustrate this by comparing the early internationalization of Latin American and Southeast Asian firms. 


\section{INTERNATIONAL POLITICAL ECONOMY}

\section{The IPE framework}

IPE is an interdisciplinary approach to trade and foreign investment that integrates economics, politics, and international relations. Most succinctly, IPE is about 'the politics of international economic relations' (Strange 1994|2015:12). IPE is therefore concerned with relationships between, on the one hand, economic and business phenomena such as output or exports, and on the other, political arrangements for example concerning international treaties, and government policy. Our analysis draws on the concept of a strong state with a capacity for embedded autonomy: the state's ability to create sufficient agency to engage constructively with business elites while simultaneously maintaining freedom from dependence upon any particular group of elites (Evans, 1995). This allows us to explore the effects of the application of the US Monroe Doctrine in Latin America on state autonomy in each country and in particular their capacity to develop coherent and effective industrial policies to support their emblematic firms (Amsden, 2001). Thus, we consider the external constraints imposed by national security arrangements on the state and the extent to which it continues to possess the necessary agency to exercise its preferences on local business elites.

Our analysis, therefore, focuses on the interaction and comparative influence of states and firms in the international political system (Stopford, Strange, \& Henley, 1991). Strange (1994) identifies four core power structures in the international bargaining process: security, the organization of production, finance and knowledge, respectively. The security structure represents a political mechanism whereby one or a few states provides security for others where security includes military protection, intelligence and policing. For example, in the post-war era, the United States provided security to Western Europe through NATO and the Soviet Union to Eastern 
Europe via the Warsaw Pact. The providers of such security acquire certain types of economic power within their alliance; their firms may also acquire particular advantages in the production, trade and the allocation of capital. For these reasons, "the security structure inevitably has an impact on the 'who-gets-what of the economy' "(Strange 1994:45).

The production structure refers to the arrangements determining what is produced by whom and for whom, by what methods, and on what terms. National factor endowments play a large part in determining the production structure, but increasingly knowledge and intellectual property play a more decisive role (Hollanders \& Soete, 2010) ${ }^{3}$. The financial structure has two components: the first determines how credit is created and allocated. Strange (1994) argues that it is credit that drives firm growth in emerging markets. The second is the monetary system that determines currency values and how much scope the state allow markets to operate the financial system (Strange, 1994: 90).

Finally, the power arising from the knowledge structures is difficult to quantify as it encompasses communications, information, skills, and knowledge asymmetries. In recent years, innovation-based services have become increasingly important vis a vis the primary and manufacturing sectors (Côté, Estrin, Shapiro, 2020). An increasingly codified body of rules, under the aegis of international organizations such as the World International Property Organization and the 1994 Agreement on Trade-Related Aspects of Intellectual Property (TRIPS), support firms' ability to extract value from knowledge. These developments created a new era of enforceable rules respecting intellectual property protection (Sell, 2010). Unlike the positive power associated with providing security, production capacity, and credit, Strange (1994) observes that influence

\footnotetext{
${ }^{3}$ Globalization has produced a new international division of labour, in which manufacturing production has shifted significantly from advanced to developing countries. Since the production structure creates wealth in the political economy, in addition to security, power is held by those who manage the location of production (Strange, 1994:64).
} 
available in the knowledge structure 'is the negative capacity to deny knowledge, to exclude others, rather than in power to convey knowledge' (p 119).

In this analysis, we explore the effects of security as a fundamental driving force that governs the functioning of the national production, finance, and knowledge structures. We therefore build on the basic IPE framework to propose that the Monroe Doctrine facilitated "the persistence of stamped-in contextual features" (Marquis \& Tilcsik, 2013:206) associated with the international security arrangements in Latin America and which had an effect on the autonomy of all the nation-states in that region. These, in turn, have had a long-lasting impact on the organization of production, finance and credit, and global knowledge flows. Consistent with industrial development theories, we posit that a strong developmental state with the autonomy to manage its production and finance structures is a necessary condition for a successful exportoriented industrial growth strategy (Amsden, 2001; Evans, 1995; Johnson, 1982; Stubbs, 2017).

\section{The Monroe Doctrine}

The US Monroe Doctrine, which defines the relevant IPE national security framework for Latin America, originated from a US commitment in 1823 to protect the Latin American states from the threat of the re-colonialization by European powers. Many Latin American states had gained their independence from Spanish and Portuguese colonial interests during the early 19th century, which stands in contrast to countries in Asia and Africa which became independent much later. In response, the US government under President Monroe developed the eponymous doctrine, which proclaimed that any attempt by European colonial powers, to retake control of an independent North or South American territory, would be considered 'a manifestation of an unfriendly disposition towards the United States' (Herring, 2008). 
Under the Monroe Doctrine, the US has evolved an expectation that it could exert its influence in the region, unchallenged by European powers or any form of collective action by Latin American states. Hence, the US State Department has retained for decades substantial influence in the affairs of Latin American countries. One scholar describes the US as a 'metapower' characterizing US relations with Latin America as one of subordination and penetrability where, "US foreign policy actions conditions the patterns of interaction not only in the system as a whole but also inside individual countries" (Nef, 2000:404). In addition, since no $19^{\text {th }}$-century European power ever posed a major security threat to Latin America, the interpretation of the Monroe doctrine evolved toward advancing US commercial interests in the region (Bucheli, 2008).

Moreover, the influence of the Monroe doctrine persisted over time. With the onset of the Cold War, the US intensified its intervention in Latin American affairs, with the creation of the Organisation of American States and the Central Intelligence Agency. Postwar efforts by Latin American states to establish reform and economic nationalism triggered US concerns that were magnified and distorted by Cold War rhetoric. Local states that attempted to assert their autonomy with left-leaning reform programs were branded as international communism by interests in the US State Department. Following the Cuban revolution 1953-8, the US began to offer military aid to Latin American governments who claimed to be threatened by a communist insurgency. The left-leaning Brazilian government in 1963, which sought to introduce reforms including a plan to socialize the profits of the large companies, faced a military coup supported by the US in 1964; this resulted in a military regime lasting 20 years (Skidmore, 1989). Similarly, Haslam (2005) provides a detailed account of US involvement in the overthrow of the left-leaning Allende regime in Chile. 
Our central contention is that the functioning of region-wide security arrangements has affected the strategy and performance of Latin American firms. The power yielded through the Monroe Doctrine resulted in the early prioritization of US MNEs in Latin American economies, confining local firms into particular industries, weakening capital markets and thus restricting the flow of funds to the enterprise sector and hindering the emergence of internationally competitive domestic firms. Moreover, it simultaneously subordinated and restricted the emergence across Latin America of strong states with sufficient agency to implement effective policies for industrial development.

Below, we briefly document below some of the Doctrine's long-lasting imprints on Latin American production, finance, and knowledge structures (Strange, 1994).

\section{The production structure}

A significant feature of the Latin American production system is the entrenched, extensive and long-term involvement of US (and other) multinationals. Their influence in maintaining their prevalence in the region is a corollary of the region's security arrangements, and a manifestation of the view that MNEs can serve as national policy instruments (Casson, 2020). Multinational enterprises comprised 39\% of Latin America's 500 largest firms in 2001 (Schneider, 2013). Indeed, the early penetration of foreign multinationals before 1945 meant that Latin American business groups formed in later periods and did not enter the sectors where MNEs already held extensive interests (Amsden, 2009). Instead, internationally competitive local firms tended to focus on resource sectors. This experience contrasts strongly with that of the successful East and South Asian developmental states, whose industrial policy began with the dislodging of MNEs and limiting the extent to which they influenced the progress of industrial development (Amsden, 2001; Encarnation, 1989; Guillen, 2000). 


\section{The finance structure}

In part as a result of US security dominance, Latin American states faced long term internal capital constraints which intensified dependence on US debt (Edmunds, 2007; Babb, 2013; Kaplan, 2016) ${ }^{4}$. Moreover, Latin American financial institutions did not attain high levels of autonomy from the US (Evans, 1995). The dominance of US firms together with underdeveloped capital markets has resulted in reliance on inter-firm finance arranged either internally within business groups or through multinational firms (Khanna \& Palepu, 2010; Morck, Wolfenson, Yeung, 2007). The Latin American experience of control of credit can be contrasted with successful developmental states in Southeast Asia where governments were able to establish control over their financial systems (Bowles, 2002).

\section{The knowledge structure}

Contrary to expectations from the IB literature (e.g. Meyer \& Sinani, 2009), the operations of MNEs in Latin America has produced few significant spillovers into the local economy. Take for example the diffusion of technology: MNEs do virtually no research in Latin American countries except for some R\&D in Brazil, (Schneider, 2013). Schneider (2013:84) summarised the situation in the following manner:

"In sum, MNCs brought a lot of capital, created jobs, and transferred some technologies. However, the broader and longer-term contributions were uneven. FDI did not increase overall investment, tended not to develop backward linkages, extended MNC control over trade, and, outside Brazil, did not bring much investment in R\&D. Over the longer term, MNCs boxed domestic firms out of several sectors and generally depressed demand for skilled workers"

More generally, US interests often constrained local states' capacity to exercise autonomy over their industrial policy as Amsden (2001:14) summarises:

\footnotetext{
${ }^{4}$ The heavy reliance by states across the hemisphere on foreign debt represents a level of financial exposure that has underlaid periodic crises. World Bank and IMF aid also resulted in deep indebtedness, especially in Argentina, Brazil, and Venezuela, and required conditionality including opening economies to trade and investment.
} 
"Argentina and Mexico, and to a lesser extent Brazil, increased their dependence for future growth on foreign know-how. In these countries, foreign investment predominated but local expenditures on science and technology by foreign investors were virtually nil... In Chile, the developmental machinery had been retired as early as 1973."

It is also the case that, in general, Latin American countries are characterized by lower levels of education, skills and training (Schneider, 2013), in part as a consequence of the widespread failure in the region to establish effective states with a capacity for embedded autonomy. Tertiary education, scientific capacity, and university-industry cooperation is underdeveloped (Peña-Vinces, Sanchez-Ancochea, Guillen, \& Aguado, 2020), with researchers identifying a widening technology gap between Latin America and East Asia (Knight \& Marques, 2008). This is likely to have led to lower absorptive capacity, thereby further limiting knowledge spillovers.

With our emphasis on the Monroe doctrine, we do not mean to underplay the complexity and heterogeneity of institutional evolution across Latin America. In particular, the doctrine is not salient in policy discourses on institutional reforms for individual countries. In the management literature, the influence of the Monroe doctrine is, at best, considered a background factor (e.g. Vassolo, de Castro, \& Gomez-Meijia, 2011). Rather, we suggest that the original imprint of the Monroe Doctrine could remain latent at times, allowing for institutional developments that involve seemingly radical changes while the protection of particular interests persists (Acemoglu \& Robinson, 2006). For example, political regimes in Latin America often cycle between populist to left-leaning governments without bringing about any notable shift in the allocation of resources or the ability of elites to extract rents. Thus, while constraining or extractive institutional mechanisms may be dismantled, the de facto effect of these institutions can persist into the future (Acemoglu, Johnson, \& Robinson, 2001).

\section{IPE and Business Groups}


Boyer (2005) argues that when analyzing the relationship between national contexts and firm-level behaviours, it is valuable to focus on organizations with the 'emblematic form'. Thus, for advanced market economies, the public corporation is usually viewed as the emblematic form, and most analysis of performance concentrates on these organizations (e.g. Morck, Wolfenzon \& Yeung, 2005; Teece, 2007). In contrast, business groups are often seen as the emblematic form in many emerging economies (Carney et al, 2018). The significant role of business groups in Latin America is a well-established phenomenon (Grosse, 2007; Schneider, 2013; Strachan, 1976). Along with a few state-owned enterprises (Musacchio \& Lazzarini, 2014) and, notably, a significant representation of multinational enterprises, family-controlled groups are the dominant corporate form in the region's largest economies, including Argentina, Brazil, Colombia, and Chile (Grosse, 2007; Schneider, 2013). For example, in Chile, business groups are the main form of corporate structure, with some 50 business groups controlling $91 \%$ of the assets of publicly listed companies, and these rates have remained stable over time (Schneider, 2013:49). In addition, governments often focus their development policies on key private organizations and in emerging economies including Latin America, this means on business groups (Onis, 1991; Schneider, 2009; Stal \& Cuervo-Cazurra, 2011). This leads us, in the Latin American context, to analyze the longterm imprint effects of the Monroe Doctrine security arrangements by considering their impact on BGs.

\section{The Performance of Latin American Business Groups}

There is a prevailing pessimistic view that the Latin America BGs, in the aggregate, are less adaptable and resilient and have not attained the levels of international competitiveness found elsewhere (Aldrighi \& Postali, 2010; Castallacci, 2015; Schneider, 2013), particularly compared to Asian business groups (Grosse, 2007). One view suggests that the most common corporate form 
of BGs in Latin America reflects a portfolio logic (Fracchia, Mesquita, \& Quiroga, 2010; Grosse, 2007; Lefort, 2010). Grosse \& Mesquita (2007:1) suggest that "it seems that most observers do not see specific competitive strengths that will indeed enable firms from Latin America to beat out the competitors from abroad in their Latin American markets or elsewhere in the world". They argue that Latin American exports and outward foreign direct investments are small in relative terms. Only three of the world's 100 largest MNEs from emerging markets have originated in Latin America (UNCTAD, 2020). Thus, for the most part Latin American firms are relatively small and regional by global standards and are relatively highly concentrated in resource-based industries (Aguilera et al, 2018; Gonzalez-Perez \& Velez-Ocampo, 2014).

Because many Latin American business groups have their origins in resource-based industries, they are driven by the commodity boom-bust cycle to diversifying in counter-cyclical industries, often within their own country (Aguilera et al, 2018). The consequence is a focus on commodity resource-based industries, as well as industries that require local and often labourintensive distribution systems. There is also a tendency to concentrate on mostly non-tradable service industries such as retailing, telecommunications, television and entertainment, electricity, and construction (Grosse, 2007). Schneider (2013:49) argues that Latin American business groups are 'exceedingly diversified' across multiple sectors such as finance, transportation, tourism, construction, commerce, and agri-industry; and that because they are subject to the commodity boom-bust cycles, Latin American business groups pursue defensive diversification.

Hence, the core logic of diversification in Latin American BGs is based upon riskminimization, which is basically a finance-driven strategy. Like the North American and European conglomerates and holding companies whose dominant corporate logic is financial, Latin American business groups do not develop strong managerial and technological capabilities 
transferable from one business to another. While their economic logic provides some protection against commodity and other macroeconomic shocks, the underlying managerial structure of the groups is typically fragile. The emphasis on a financial logic is consistent with evidence that Latin American business groups tend to churn, with the regular rise and fall of particular groups. For example, some have collapsed and disappeared, while other BGs acquire their constituent businesses (Grosse, 2007; Larrain \& Urzúa, 2016). The financial portfolio structure therefore implies that the BG form persists but with a continued emphasis on survival in the domestic market as the assets of failed business groups, which are bundled into new business groups under different ownership. Grosse concludes that while Latin American BGs have developed capabilities designed to ensure survival in the face of competition from foreign MNEs these are rooted in "superior knowledge of and ability to navigate local markets, which in turn have inefficiencies and imperfections that more open competition has not resolved" (Grosse 2007:41).

This contrasts with the Khanna and Palepu (2010) depiction of efficient internationalization of BGs by creating group-level internal markets, especially for capital, skilled labour, management and knowledge. The literature abounds with examples of advantages stemming from business group affiliation, especially in providing resources in support of internationalization (Khannah \& Yafeh, 2007; Carney, Estrin, van Essen \& Shapiro, 2018). Thus it is argued that experienced BG executives can advise affiliates on how to develop their international projects (Amsden \& Hikino, 1994) and that BGs can improve their global competitiveness by importing and disseminating technologies and practices from more advanced economies among group affiliates (Chari \& Dixit, 2015). Other research suggests BGs are catching up to the international productivity frontier by developing proprietary organizational capabilities 
and product innovations (Belenzon \& Berkovitz, 2010), and that these capabilities increase their international scope (Ayyagari, Dau, \& Spencer, 2015).

Thus, we suggest that Latin American BGs are different from their more internationally competitive namesakes, often from Asia; this is a regional rather than a country specific effect. To understand why, we explore international political economy reasons, namely that the substantial US presence under auspices of the Monroe Doctrine has effectively denied Latin American states the autonomy needed to develop and implement a long-term industrial policy. As a corollary of the deep and regionally based US influence, there has been a significant and long term penetration of mainly US multinational enterprises in the region's economies, which have 'boxed out' domestic firms from high-technology manufacturing-based industries. Competing in such a context, Latin American business groups have chosen to develop a domestically focused portfolio to counter resource-based boom-bust cyclicality, with a finance motivated risk diversification strategy.

We summarize this analysis by the following proposition:

The persistent impact of security arrangements stemming from the Monroe Doctrine in Latin America has led to a tendency among all firms in the region for domestic operations over exporting, especially in the emblematic organizational form, the business group.

It is important to note that we do not propose that all Latin American countries and firms are homogeneous. We recognize that different countries have experienced different degrees of political stability, have engaged in different sets of reforms, and have different resource endowments (Cuervo-Cazurra, 2016; Aguilera et al, 2018). Our proposition is that the imprint of the Monroe Doctrine persists even after controlling for these factors (Acemoglu, Johnson \& Robinson, 2001). We now explore some evidence in support of the proposition, using regression analysis. 


\section{DATA AND METHODS}

We use firm level performance data across emerging economies to explore the proposition empirically while controlling for alternative explanations To do this, we draw on the World Bank Economic Surveys (WBES) (http://data.worldbank.org/data-catalog/enterprise-surveys) which collected data over 120,000 firms in emerging economies across Asia, Latin America, Eastern and Central Europe, and Africa between 2006 and 2016 using a standard methodology (World Bank, 2011. The data have three dimensions: firm, country and region. Table 1 lists the 39 countries and numbers of firms (frequency) in each region in the WBES database. After accounting for missing values and eliminating firms with fewer than ten employees and foreign and state-owned firms, the sample available is over 35,000 firms from all countries, more than 10,000 of which are from Latin America.

\section{-Table 1 about here-}

Since our interest is early international competitiveness, we focus on exporting performance, long regarded as a key indicator of organizational performance (Bernard et al, 2018), and a measure of early internationalization (Gaur et al, 2014; Conconi, Sapir, \& Zanardi, 2016). We follow the literature (Estrin, Meyer, Wright \& Foliano, 2008; He, Brouthers, \& Filatotchev, 2013; Wang \& Ma, 2018) in using export intensity (EXPORT), as our measure of firm performance. This is defined as the percentage of direct exports in total sales. 
The data also indicates whether a firm is affiliated to a business group ${ }^{5}$. We distinguish between firms that self-identify as being group member - group affiliated $(G A F)$ - and those that do not, coded as 1 , and 0 respectively.

Our proposition concerns the impact of regional location in Latin America on firm-level internationalization, especially for business group affiliates. We therefore include a regional dummy variable $(L A)$ that takes a value of unity for firms located in Latin America, namely Argentina, Brazil, Chile, Colombia, Peru and Venezuela. Mexico represents a moot case: it was included in the Monroe Doctrine but is also a member of NAFTA. In our main results, we assume the Latin America dummy variable excludes Mexico, but we report in the Appendix the same regression but with Mexico included in the dummy variable. In our regressions, we consider the direct effects of regional location and group affiliation (at the firm level) on the company's export performance. We also explore whether regional location effects moderate the relationship between group affiliation and export performance by including an interaction term between the two.

We control both for firm- and country-level heterogeneity. The literature on the relative performance of firms in Latin America has concentrated on two related explanations of their lacklustre performance: the natural resource curse and rent-seeking elites (Acemoglu \& Robinson, 2012: Mudambi, 2018). The resource curse argument is that in countries that are rich in natural resources, a variety of factors conspire, separately and together, to limit the pace of economic development and the evolution of firms (Auty, 2001; Venables, 2016; Shapiro, Hobdari \& Oh, 2018). For example, Mudambi (2018:46) argues that "resource abundance deprives decisionmakers of incentives to develop knowledge-intensive intangibles." We control for the former

\footnotetext{
${ }^{5}$ WBES applies a standard definition of group affiliation across jurisdictions which requires that firms identifying themselves as group members must be independent, an important feature of emerging market business groups (Castellacci, 2015).
} 
using the measure of resource dependency from the World Development Indicators (WDI); that is natural resources rents as a percentage of GDP.

The notion of elite capture suggests special interest groups such as powerful industrial oligarchs or a landowning aristocracy, can exploit their political and economic power to entrench their interests (Fogel, 2006; Morck et al, 2005) by capturing the state and encouraging the formation of extractive institutions designed to generate rents for elite groups (Acemoglu \& Robinson, 2012). This relates to a number of different indicators of formal and informal institutions concerning governance, corruption, external dependency and political stability. In our regressions, we use two indicators from the Worldwide Governance Indicators (WGI), namely for government efficiency and corruption ${ }^{6}$.

We also use firm-level variables to control for the impact of heterogeneity in company performance. Larger firms are likely to be more productive (Hall \& Weiss, 1967), and are more likely to export (Chen, Sousa, \& He, 2016; Bernard et al, 2018) so we control for Firm Size, measured by the number of permanent employees. Following previous literature on exports, we also control for firm age as a broad index of firm capabilities (a positive effect) or as an indication of firm entrenchment (a negative effect), both of which are found in the literature (Dhanaraj \& Beamish, 2003; LiPuma Newbert, \& Doh, 2013; Love, Roper, \& Zhou, 2016). We measure Firm Age by years of operation since the firm's establishment. To address potential issues of nonnormality, these variables are entered in logs. Finally, to reduce heterogeneity of the estimates, we

\footnotetext{
${ }^{6}$ In unreported robustness tests, we additionally employ a variety of alternative indicators of political governance. Thus, we include: aid dependency from the World Bank, measured by the proportion of government spending that is given by foreign donors, $\mathrm{s}$ well as the remaining measures in the WGI series. We also use an alternative indicator of the political system, namely, the Political Constraint Index (POLCON), a measure of political and social stability (Henisz, 2000).
} 
include fixed effects, both for time and industry. We report variable definitions and sources for all dependent and independent variables in Table 2.

\section{-Table 2 about here-}

We report descriptive statistics and correlation coefficients in Table 3 and the regression results in Table 4. The correlation coefficients between the independent variables are almost all small, mostly well below 0.1, except firm age and size which are correlated at a level around 0.3. Additionally, we perform a VIF (variance inflation factor) test to detect multicollinearity. The Mean VIF for all variables was 6.11 with year and industry dummies; 2.19 without. Both values are well below the "rule of thumb" critical value at 10 , further indicating that multicollinearity is not a severe issue in our data.

\section{-Table 3 about here-}

In our estimating equation, we use the dataset to explore the differences between Latin American firms and firms in all the other developing countries in our sample. The omitted regional category is the rest of the world. Our estimating equation is therefore:

\section{Export $=\mathbf{a}_{1}+\mathbf{a}_{2} \ln ($ firm age $)+\mathbf{a}_{3} \ln ($ firm size $)+\mathbf{a}_{4}($ resource dependency $)+\mathbf{a}_{5}($ elite capture $)+a_{6}($ GAF $)+a_{7} \mathbf{L A}+\mathbf{a g}_{8} \mathbf{G A F} * \mathbf{L A}+\sum$ industry dummies $+\sum$ time dummies.}

We estimate three specifications using OLS. In the first, we include all the independent and control variables except for the LA dummy. In the second, we add the LA dummy variable, which is expected to carry a negative sign $\left(a_{7}<0\right)$ and in the third we also include an interaction between group affiliation and the LA dummy to explore whether the negative LA effect is more pronounced for business groups $\left(\mathrm{a}_{8}<0\right)$.

\section{RESULTS}


We report our results in Table 4. We note from Model 1 that the independent variables are all statistically significant with the expected signs; hence exports are higher in larger and younger firms, and in countries with higher government efficiency and lower resource dependency and corruption. Furthermore, we find that group affiliation has a positive effect on firm internationalization across our entire sample of emerging market firms: GAF is found to be positive and significant.

\section{-Table 4 about here-}

Consistent with our IPE framework, we find in Model 2 that regional location in Latin America exerts a significant negative independent effect on export performance, even when we control for the above firm- and country-specific factors. Thus, all firms located in Latin America have, on average, an inferior export performance compared with firms from all other emerging economies in our sample. This effect holds regardless of whether or not firms are affiliated with business groups.

Finally, we find in Model 3 that group affiliation leads to a more pronounced deterioration in export performance in Latin America compared with the rest of the world. The regression identifies a significant negative moderating effect of the LA dummy on the relationship between group affiliation and export performance. Taken together, Models 2 and 3 therefore tell us that being located in Latin America significantly reduces export performance, and that group affiliation accentuates this negative effect. Indeed, while the impact of group affiliation across the world in Model 1 is positive, with a coefficient of 1.060, the net effect of business groups in Latin America, taking account of the direct and moderated term, is negative $(1.677-4.037=-2.36)$. Thus, consistent with our proposition, we find that being located in Latin America reduces the export 
performance of all firms, relative to firms in all other developing countries in our sample, and group affiliation reduces the performance even further.

In Appendix Table A1, we report a re-estimation of Table 1 in which Mexico is included as part of the Latin American region. The results provide a consistent interpretation about the effects of LA, BG and their interaction to that in Table 1.

We also undertook additional regressions to ensure that our findings with respect to the impact of the Latin American regional grouping were not driven by the omission of key countryspecific variables capturing the impact of elite capture. In these unreported regressions, available from the authors on request, we included separately and jointly all six WGI governance variables (voice of accountability; political stability; regulation quality; rule of law) as well as an indicator of political and social stability POLCON. The results confirm our previous analysis with a consistent and negative sign on the interactive term between Latin America and the business group affiliate dummies.

\section{DISCUSSION}

The process whereby firms evolve their international market engagement may operate differently in emerging economies from developed economies, and in the former, there may also be considerable heterogeneity of experiences (Estrin et al., 2019). Thus, while the literature has compared the internationalization processes of MNEs from developed and emerging markets, the differences among different emerging markets may also be very marked (Goldstein, 2007; Ramamurti \& Singh, 2009). In this paper, we extend the understanding of the boundary conditions surrounding the heterogeneity of internationalization experiences of firms, in particular business group affiliated firms, in emerging markets. Our main contributions have been to draw on IPE to introduce to the international business strategy literature the potential importance of regional 
geography ${ }^{7}$ and geopolitics in explaining firm-level outcomes, and in understanding the mechanisms by which emblematic organizational forms, such as business groups, influence the performance of their affiliates.

To identify the potential role of geographic location for firm performance, we have drawn on theories of international political economy. The IPE perspective offers a geopolitical understanding that a set of geographically contiguous countries can develop and evolve similar institutional features that can go on to determine the nature of corporate strategies and structures in that particular regional location. Moreover, these institutional characteristics may have been formed in the past, and their effects may persist. We focus in this paper on one principal determinant of regional similarity: the security framework. We concentrate our attention on Latin America where former European colonies all achieved relatively early independence and identify the resulting imprinting on firm behavior: how their subsequent security arrangements have influenced the national structures of production, finance and global knowledge flows, and thereby the early internalization of domestic business groups.

We suggest that the security arrangements for Latin America stemmed from the Monroe Doctrine of 1823 which led to a domestic orientation with firms largely denied US market access while competing within domestic markets with primarily US MNEs. This framework gave little incentive to transfer know-how to local firms and left little role for business groups as agents for state-sponsored export-led development. Consequently, business groups in Latin America often grew out of natural resource sectors and tended to follow a portfolio approach designed to mitigate

\footnotetext{
${ }^{7}$ By geography, we do not refer to issues of natural features or resources, transportation, or national location. Instead, we focus on the notion that, for firms in some countries, a relevant contextualisation for their behaviour is that they belong to a particular geographic configuration, that is a group of countries defined by their location.
} 
macroeconomic instability and the commodity cycle risk. Hence, they did not play a role leading the process of internationalization through exporting and innovation.

Thus, we suggest that under an evolving Monroe doctrine, Latin American states have been unable to implement a long-term industrial policy of domestic export-oriented development to reduce economic dependence on natural resources. This stands in contrast to most Asian countries which achieved independence much later and which have had more autonomy in developing policies that facilitated an export-led strategy, often centred around business groups (Amsden, 2001; Evans, 1996). Indeed, with the early penetration of US MNES, Latin American business groups not only formed later but did not enter industrial sectors occupied by foreign firms (Amsden, 2009).

Empirically, we find strong and consistent evidence that in terms of export performance, there is a Latin American effect, such that other things constant, all Latin American firms, nonstate and non-foreign, will export less. Moreover, in Latin America, unlike in all the other emerging market regions around the world, -group affiliates do not outperform independent firms, a finding that seems to defy conventional wisdom about the competitive advantages of BG affiliates (Holmes, Hoskison, Kim, Wan, \& Holcomb, 2018). Indeed, we also find Latin American group affiliates have the lowest export intensity of all group affiliates from emerging economies.

An important feature of our results is that the analysis takes into account the major alternative explanations of weak enterprise performance in Latin American firms, namely the resource curse and elite capture (Venables, 2016; Mudambi, 2018), in an exacting specification which includes industry- and time-specific fixed effects. In fact, we find that as predicted both high levels of resource dependency and higher levels of elite capture (for example, greater government efficiency and less corruption) act to reduce firm performance in Latin America. 
However, even controlling for these two country-specific explanations of performance, we still find a significant extra-country effect across all Latin American firms, whether or not we include Mexico in our definition of Larin America, and one which impacts more on business groups than on non-affiliated firms. We propose that this result is a consequence of imprinting arising from the longstanding effects of the Monroe doctrine on economic policymaking across the region.

These results may be contrasted with existing approaches to grouping countries by shared institutional characteristics. For example, Fainschmidt et al (2016) group Brazil, Mexico and Colombia together with Nigeria and Morocco, while Chile and Venezuela are in different groups. Similarly, Witt et al (2018), also put Chile and Venezuela in different groups, separate from Brazil, Mexico and Colombia. Although there is empirical evidence that such groupings have meaning (Carney et al, 2019), our approach suggests that they may also ignore significant sources of homogeneity arising from IPE factors that have important consequences for understanding the international competitiveness of emerging market firms and in particular BGs.

The IPE approach also contributes to a deeper understanding of the nature and performance of Multilatinas, a topic that has recently been prominent in the literature (Aguilera et al, 2018), with particular emphasis on their home country characteristics and reasons why their global presence is limited (Cuervo-Cazurra, 2016). Aguilera et al (2018) point out that there is debate over both the spatial boundaries of Latin America, and the role played by shared history as opposed to differences across countries. As they note "Latin America is thus one and many - it is a region with some clearly shared features, such as having been colonies, mostly of Spain and Portugal, and being rich in natural resources; but also one with a high heterogeneity in terms of wealth, economic diversification, and political structures” (p. 449). Our approach and our empirical results reinforce this point. After controlling for potential sources of home country heterogeneity, we still 
find that there is a Latin American "one", which we argue is defined by a shared geo-political history; one which exerts a negative impact on the early internationalization of its firms.

The IPE approach suggests that the inward FDI from American firms to Latin America did not result in the kinds of spillovers that lead to further economic development, as suggested by the Investment Development Path (IDP) proposed by John Dunning (1981). It is understood in the IDP literature that there may be considerable heterogeneity across countries (Dunning and Narula, 1998; Globerman \& Shapiro, 2008), including Latin America (Stal \& Cuervo-Cazurra, 2011; Borda, Newburry, Carneiro, \& Cordova, 2019) and Central and Eastern Europe (Stoian, 2013), and that these differences may result in divergent development paths. Our analysis points to the possibility of an interrupted IPD whereby inbound FDI does not result in the spillovers that support the development of domestic MNEs, and more importantly that this may characterize all firms across a region.

We base our approach on the idea that regional location is potentially significant for firm performance, but we acknowledge this is not always the case, or at least that both country heterogeneity and regional homogeneity may co-exist. It is therefore vital to have a theoretical understanding of the mechanisms linking the region with enterprise strategy. We have proposed that IPE represents a suitable methodology to analyze this mechanism. Nevertheless, it is feasible that some regions are too diverse and heterogeneous in terms of a security framework to coherently influence firm performance; this is an important question for future research. Thus, researchers may wish to develop these ideas to explore whether theoretical factors are leading to regional effects in other parts of the world; obvious candidates might include the European Union (or the European Monetary Union) and sub-Saharan Africa. 
Our analysis has focused on security arrangements that were imposed on a region. However, one could also identify regions to study based on voluntary security arrangements, leading to a different IPE history. For example, in order to both defend against the threat of communism, and to thwart Western ambitions in the region, five Asian states (Indonesia, Malaysia, Philippines, Singapore, and Thailand) in 1967 formed ASEAN, the Association of Southeast Asian Nations. This later expanded to members and became more of a trade organization when the communist threat receded (Acharya, 2001) ${ }^{8}$. Indeed, it has recently (November 2020) concluded the Regional Comprehensive Economic Partnership (RCEP) with China, Australia, New Zealand Japan and South Korea.

Unlike in Latin America, Southeast Asian states have jealously guarded their sovereignty (Narine, 2012). ASEAN member states created and controlled their security apparatus and established efficient central bureaucracies (Stubbs, 1999). As a result, they have retained relative autonomy from the US, and as autonomous states, they have been able to execute industrial policies to reduce dependence upon natural resources. While transitioning from import substitution and to reduce their economic dependence on resource exports, they also attempted to imitate the success of East Asia's export-oriented development strategy (Stubbs, 2017). This led them to support the emergence and growth of business groups in the region (McVey, 1992; Carney \& Gedajlovic, 2002) to create a manufacturing capability integrated into global commodity chains (Baldwin, 2016; Hobday, 2001; Rauch \& Trinade, 2002;).

This grouping, also founded around national security arrangements but much more effective in terms of the embedded state autonomy, represents an interesting point of comparison

\footnotetext{
${ }^{8}$ The US originally attempted to develop a security arrangement in the region known as SEATO (Southeast Asia Treaty Organization), in which it would participate. SEATO failed, but the US provided extensive military assistance to south-east Asian states which governments used to build up physical infrastructure, substantial military, and a strong bureaucracy (Stubbs, 1999).
} 
with Latin America. In regressions reported in the Appendix Table A2, we explore a comparison between Latin America and four of the original ASEAN countries. We find that the effects of business group affiliation in Southeast Asia are positive and significant, precisely the opposite of the findings for Latin America. This suggests that the nature of security arrangements can matter. Specifically, the performance of the ASEAN BG affiliates supports the view that more autonomous states could pursue an industrial policy to develop capabilities supportive of early internationalization via exporting.

However, the analysis may extend beyond security arrangements. Decades of globalization have been characterized by the establishment of a rules-based order governing bilateral and multilateral investment and trade relationships between states, and these constrain the national ability to realize purely domestic policy preferences (Rodrik, 2020). This relates to Strange's notion (1994) of knowledge structures, which can influence firm performance through its capacity to deny access to knowledge. Accordingly, we suggest that the IPE framework can be an insightful and timely perspective from which to view a broader set of international relations between countries, the current tensions surrounding them, and their impact on firm internationalization.

Finally, our application of the IPE perspective has emphasized the importance of history, in our case geopolitical history, to the understanding of the evolution of both countries and firms. We therefore fully endorse the suggestion that future studies in IB should carefully consider political history both within and between states (Casson, 2020). In our historical application of the IPE we have referred to the imprinting literature (Marquis \& Tilcsik, 2013; Simsek et al, 2015) as a means of understanding the ways in which historical events become embedded in current practices (Kriauciunas \& Kale, 2006). Marquis \& Tilcsik (2013:205) distinguish between imprinting and path dependence based in part on differences in the nature of the initial event (a 
prominent event for imprinting versus an historical accident for path dependence), and the persistence of the effect (which they suggest is greater for imprinting). At the same time, there is increased recognition of the need to refine the understanding of path dependence in the context of geo-historical development (Martin \& Sunley, 2006). We believe that the IB literature would benefit from further explorations along these lines.

\section{CONCLUSIONS}

We employ an IPE conceptual framework in which the historical application of a specific security arrangement, in our case the Monroe Doctrine, affects the development of a region and its firms. Specifically, we have argued that the impact of the Monroe Doctrine has meant that firms throughout the region are less likely to engage in exporting, and this is particularly true of regional business groups. Holding constant both firm- and country-specific factors that might promote heterogeneity, we find consistent and robust evidence that Latin American business group affiliates are less likely to engage in exporting than affiliates in the rest of the world. We propose that this outcome is linked to the IPE arrangements and the IPE security structures that have a profound and lasting impact on the emblematic BG firms and their internationalization capacity in each region.

While we acknowledge its exploratory nature, our main contribution has been to introduce to the international strategy literature the potential importance of shared regional geopolitical history and geography in explaining firm-level outcomes, and in understanding the mechanisms by which emblematic organizational forms, such as Business Groups, emerge and influence the performance of their affiliates. The IPE perspective offers a geopolitical understanding that a set of geographically contiguous or related countries can develop and evolve similar institutional 
features that can go on to determine the nature of corporate strategies and performance in that regional location. Moreover, we point to the ways in which geopolitical histories can differ, and result in different outcomes in terms of firm performance. Thus, we also contribute to an understanding of the comparative nature of business group performance around the world. 


\section{REFERENCES}

Acemoglu, D., Johnson, S., \& Robinson, J. A. (2001). The colonial origins of comparative development: An empirical investigation. American economic review, 91(5), 1369-1401.

Acemoglu, D., \& Robinson, J. A. 2012. Why Nations Fail. New York, NY: Crown Business.

Acemoglu, D., \& Robinson, J. A. (2006). De facto political power and institutional persistence. American Economic Review, 96(2), 325-330.

Aguilera, R. V., Ciravegna, L., Cuervo-Cazurra, A., \& Gonzalez-Perez, M. A. 2018. Multilatinas and the internationalization of Latin American firms. Journal of World Business, 52(4): 447-460.

Aguilera, R.V, Crespi-Cladera, R., Infantes-Sanchez, P., \& Pascual-Fuster, B. 2020. Business Groups and Internationalization: Effective Identification and Future Agenda. Journal of World Business 55(4): 10105. https://doi.org/10.1016/j.jwb.2019.101050

Aldrighi, D. \& Postali, F. 2010. Business Groups in Brazil. In Colpan, A. M., Hikino, T., \& Lincoln, J. R. (Eds), Oxford Handbook of Business Groups: 253 - 386. Oxford University Press.

Amsden, A. H. 2001. The rise of "the rest": challenges to the west from late-industrializing economies. Oxford University Press, USA.

Amsden, A. H. 2009. Does firm ownership matter? POEs vs. FOEs in the developing world. In Ramamurti R \& Singh. J (Eds). Emerging multinationals in emerging markets: 64-78. Cambridge University Press

Amsden, A. H., \& Hikino, T. 1994. Project execution capability, organizational know-how and conglomerate corporate growth in late industrialization. Industrial and corporate change, 3(1): 111-147.

Acharya, A. 2001. Constructing a security community in Southeast Asia: ASEAN and the problem of regional order. Routledge.

Argyres, N. S., De Massis, A., Foss, N. J., Frattini, F., Jones, G., \& Silverman, B. S. 2020. History-informed strategy research: The promise of history and historical research methods in advancing strategy scholarship. Strategic Management Journal, 41: 343-368.

Auty, R. M. (Ed.). (2001). Resource abundance and economic development. Oxford University Press.

Ayyagari, M., Dau, L. A., \& Spencer, J. 2015. Strategic responses to FDI in emerging markets: Are core members more responsive than peripheral members of business groups?. Academy of Management Journal, 58(6): 1869-1894.

Babb, S. 2013. The Washington Consensus as transnational policy paradigm: Its origins, trajectory and likely successor. Review of International Political Economy, 20(2): 268-297.

Baldwin, R. 2016. The Great Convergence: Information Technology and the New Globalization. Cambridge, Mass.: Harvard University Press. 
Belenzon, S., \& Berkovitz, T. (2010). Innovation in business groups. Management Science, 56(3): 519-535.

Bernard, A., Jensen, B., Redding S., \&. Schott, P. 2018. Global Firms, Journal of Economic Literature, 56(2): 565-619.

Borda Reyes, A., Newburry, W., Carneiro, J., \& Cordova, C. 2019. Using Latin America as a research laboratory: The moderating effect of trade openness on the relationship between inward and outward FDI. Multinational Business Review, 27(2): 122-140.

Bowles, P. 2002. Asia's post-crisis regionalism: bringing the state back in, keeping the (United) States out. Review of International Political Economy, 9(2): 244-270.

Boyer, R. 2005. How and why capitalisms differ. Economy and society, 34(4): 509-557

Bucheli, M. 2008. Negotiating under the Monroe doctrine: Weetman Pearson and the origins of US control of Colombian oil. Business History Review, 82(3): 529-553.

Cantwell, J., Dunning, J. H., \& Lundan, S. M. 2010. An evolutionary approach to understanding international business activity: the co-evolution of MNEs and the institutional environment. Journal of International Business Studies, 41: 567-86.

Carney, M., Van Essen, M., Estrin, S., \& Shapiro, D. 2018. Business Groups reconsidered: beyond paragons and parasites. Academy of Management Perspectives, 32(4): 493-516.

Carney, M., Estrin, S., Liang, Z., \& Shapiro, D. 2019. National institutional systems, foreign ownership and firm performance: The case of understudied countries. Journal of World Business, https://doi.org/10.1016/j.jwb.2018.03.003.

Carney, M., Gedajlovic, E. R., Heugens, P. P., Van Essen, M., \& Van Oosterhout, J. (2011). Business group affiliation, performance, context, and strategy: A meta-analysis. Academy of Management Journal, 54(3), 437-4

Carney, M., Gedajlovic, E., \& Yang, X. 2009. Varieties of Asian capitalism: Toward an institutional theory of Asian enterprise. Asia Pacific Journal of Management, 26(3): 361-380.

Carney, M., \& Gedajlovic, E. 2002. The co-evolution of institutional environments and organizational strategies: The rise of family business groups in the ASEAN region. Organization Studies, 23(1): 1-29.

Casson, M. 2019. The making of global business in long run perspective. In Teresa da Silva, L., Lubinski, C. and Tworek, H. (Eds.), The Routledge Companion to the Makers of Global Business: 35-54. Abingdon, UK: Routledge.

Casson, M. 2020. International rivalry and global business leadership: an historical perspective. Multinational Business Review, 28 (4): 429-446. 
Castellacci, F. 2015. Institutional voids or organizational resilience? Business groups, innovation, and market development in Latin America. World Development, 70: 43-58.

Chan, C. S., \& Pattnaik, C. (2021). Coevolution of home country support and internationalization of emerging market firms. International Business Review, https://doi.org/10.1016/j.ibusrev.2021.101809

Chari, M. D., \& Dixit, J. (2015). Business groups and entrepreneurship in developing countries after reforms. Journal of Business Research, 68(6), 1359-1366.

Chen, J., Sousa C.M.P., \& He, X. 2016. The determinants of export performance: a review of the literature 2006-2014, International Marketing Review, 33(5): 626-670.

Chung, C. N. 2001. Markets, culture and institutions: The emergence of large business groups in Taiwan, 1950s-1970s. Journal of Management Studies, 38(5): 719-745.

Conconi, P., Sapir, A., \& Zanardi, M. (2016). The Internationalization Process of Firms: from Exports to FDI. Journal of International Economics 99:16-30.

Côté, C., Estrin, S. \& Shapiro, D. 2020. Expanding the international trade and investment policy agenda: The role of cities and services. Journal of International Business Policy 3: 199-223.

Cuervo-Cazurra, A. 2016. Multilatinas as sources of new research insights: The learning and escape drivers of international expansion. Journal of Business Research, 69(6): 1963-1972.

Cuervo-Cazurra, A., Gaur, A., \& Singh, D. 2019. Pro-market institutions and global strategy: The pendulum of pro-market reforms and reversals. Journal of International Business Studies, 50(4): $598-632$.

Cuervo-Cazurra, A., Luo, Y., Ramamurti, R., \& Ang, S. H. 2018. Impact of the home country on internationalization. Journal of World Business, 53(5): 593-604.

Deng, P., Delios, A. \& Peng, M.W. 2020. A geographic relational perspective on the internationalization of emerging market firms. Journal of International Business Studies 51: 5071.

Dhanaraj, C. \& Beamish, P.W. 2003. A resource-based approach to the study of export performance, Journal of Small Business Management, 41(3): 242-261.

Diamond, J. 2013. Guns, germs and steel: a short history of everybody for the last 13,000 years. Random House.

Dunning, J.H. 1981. Explaining the International Direct Investment Position of Countries: Towards a Dynamic or Developmental Approach. Weltwirtschaftliches Archiv: 119, 30-64.

Dunning, J.H. \& Narula, R. 1998. The investment development path revisited. Chapter 1 in Dunning, J.H. \& R. Narula. (Eds.), Foreign Direct Investment and Governments: 1-40. UK: Routledge. 
Edmunds J.C. 2007. National financial systems in Latin America: attributes, credit allocation and practices and their impact on enterprise development. In Grosse, R., \& Mesquita, L. F. (Eds.), Can Latin American Firms Compete? 309-339. Oxford University Press.

Encarnation, D. J. 2019. Dislodging multinationals: India's strategy in comparative perspective. Cornell University Press.

Estrin, S., Meyer, K., Wright, M., \& Foliano, F. 2008. Export propensity and intensity of subsidiaries in emerging economies. International Business Review, 17 (5): 574-586.

Estrin, S., Meyer, K. E., Nielsen, B. B. and Nielsen, S. 2016. Home country institutions and the internationalization of state owned enterprises: a cross-country analysis. Journal of World Business, 51: 294-307.

Estrin, S., Mickiewicz, T., Stephan, U., \& Wright, M. 2019. Entrepreneurship in emerging markets. In R. Grosse and K. Meyer, (Eds), The Oxford Handbook of Management in Emerging Markets. Oxford: Oxford University Press.

Evans, P. 1995. Embedded Autonomy: states and industrial transformation. Princeton, N.J.: Princeton University Press.

Fainshmidt, S., Judge, W. Q., Aguilera, R. V., \& Smith, A. 2016. Varieties of institutional systems: A contextual taxonomy of understudied countries. Journal of World Business. Doi: 10.1016/j.jwb.2016.05.003.

Filkins, D. 2019. John Bolton on the Warpath._The New Yorker. April 29, 2019.

Fogel, K. 2006. Oligarchic family control, social economic outcomes, and the quality of government. Journal of International Business Studies, 37(5): 603-622.

Fracchia, E., Mesquita, L. \& Quiroga, J. 'Business Groups in Argentina', in Colpan, A. M., Hikino, T., \& Lincoln, J. R. (Eds), Oxford Handbook of Business Groups: 325-352. Oxford University Press.

Gaur, A. S., Kumar, V., \& Singh, D. T. 2014. Institutions, resources, and internationalization of emerging economy firms. Journal of World Business, 49 (1): 12-20.

Globerman, S. \& Shapiro, D. 2008. Outward FDI and the Economic Performance of Emerging Markets. In Karl P. Sauvant, with Kristin Mendoza, \& Irmak Ince (Eds.). The Rise of Transnational Corporations from Emerging Markets: Threat or Opportunity? 229 -271.

Cheltenham, 2008: Edward Elgar.

Goldstein, A. 2007. Multinational Companies from Emerging Economies Palgrave Macmillan, London. 
Gonzalez-Perez, M.A., \& Velez-Ocampo, J.F. 2014. Targeting one's own region:

Internationalisation trends of Colombian multinational companies. European Business Review, 26(6): 531-551.

Grosse, R. 2007. The role of economic groups in Latin America. In Grosse, R., \& Mesquita, L. F. (Eds.). Can Latin American Firms Compete? 29-44. Oxford University Press.

Guillen, M. F. 2000. Business groups in emerging economies: A resource-based view. Academy of Management Journal, 43(3): 362-380.

Hall, M., \& Weiss, L. (1967). Firm size and profitability. The Review of Economics and Statistics, 319-331.

Haslam, J. The Nixon administration and the death of Allende's Chile: a case of assisted suicide. Verso, 2005.

He, X., Brouthers, K.D., \& Filatotchev, I. 2013. Resource-based and institutional perspectives on export channel selection and export performance, Journal of Management, 39(1): 27-47.

Henisz, W. J. 2000. The institutional environment for economic growth. Economics \& Politics, 12(1): 1-31.

Herring, G. C. 2008. From Colony to Superpower: U.S. Foreign Relations Since 1776. New York: Oxford University Press.

Hobday, M. 2001. The electronics industries of the Asia-Pacific: Exploiting international production networks for economic development. Asian-Pacific Economic Literature, 15(1): 1329.

Hollanders, H., \& Soete, L. 2010. The growing role of knowledge in the global economy. UNESCO Science Report 2010: 1-27.

Holmes Jr, R. M., Hoskisson, R. E., Kim, H., Wan, W. P., \& Holcomb, T. R. 2018. International strategy and business groups: A review and future research agenda. Journal of World Business, 53(2): 134-150

Hu, H.W., Cui, L. \& Aulakh, P.S. 2019. State capitalism and performance persistence of business group-affiliated firms: A comparative study of China and India. Journal of International Business Studies 50(2): 193-222.

Iammarino, S., \& McCann, P. 2013. Multinational and economic geography: Location, technology, and innovation. Cheltenham, UK: Edward Elgar.

Jackson, G. and Deeg, R. 2008. Comparing capitalisms: understanding institutional diversity and its implications for international business. Journal of International Business Studies, 39: 540-61. 
Johnson, C. 1982. MITI and the Japanese miracle: the growth of industrial policy: 1925-1975. Stanford University Press.

Khanna, T., \& Palepu, K. 2000. The future of business groups in emerging markets: Long run evidence from Chile. Academy of Management Journal, 43: 268-285.

Khanna, T., \& Palepu, K. G. 2010. Winning in emerging markets: A road map for strategy and execution. Harvard Business Press

Khanna, T., \& Yafeh, Y. 2007. Business groups in emerging markets: Paragons or parasites? Journal of Economic Literature, 45(2): 331-372.

Kaplan, S. B. 2016. Banking unconditionally: the political economy of Chinese finance in Latin America. Review of International Political Economy, 23(4): 643-676.

Keister, L. A. 1998. Engineering growth: Business group structure and firm performance in China's transition economy. American journal of sociology, 104(2): 404-440.

Knight, P.T. \& Marques, R.A. 2008. Closing the Technology Gap. In: Haar J., Price J. (Eds.) Can Latin America Compete? Palgrave Macmillan, New York.

Kriauciunas, A. \& Kale, P. 2006. The impact of socialist imprinting and search on resource change: A study of firms in Lithuania. Strategic Management Journal, 27(7): 659-679.

Larrain, B., \& Urzúa I, F. 2016. Do business groups change with market development? Journal of Economics \& Management Strategy, 25(3): 750-784.

Lazzarini, S.G. 2015. Strategizing by the government: Can industrial policy create firm-level competitive advantage? Strategic Management Journal, 36: 97-112.

Lefort, F. 2010. Business Groups in Chile. In Colpan, A. M., Hikino, T., \& Lincoln, J. R. (Eds). Oxford Handbook of Business Groups: 387-423. Oxford University Press.

LiPuma, J., Newbert, S., \& Doh, J. 2013. The effect of institutional quality on firm export performance in emerging economies: A contingency model of firm age and size. Small Business Economics, 40: 817-84.

Lopes, T., Casson, M. and Jones, G. (2019), "Organizational innovation in the multinational enterprise: internalization theory and business history", Journal of International Business Studies, 50(8): 1338-1358.

Love, J. H., Roper, S., \& Zhou, Y. 2016. Experience, age and exporting performance in UK SMEs. International Business Review, 25(4): 806-819.

Mahmood, I., Zhu, H., \& Zajac, E. 2011. Where Can Capabilities Come from? Network Ties and Capability Acquisition in Business Groups. Strategic Management Journal, 32: 820-848. 
Marano, V., Arregle, J.-L., Hitt, M. A., Spadafora, E., \& van Essen, M. 2016. Home country institutions and the internationalization-performance relationship. Journal of Management, 42: 1075-110.

Marquis, C. and A. Tilcsik. 2013. Imprinting: Toward a Multilevel Theory. Academy of Management Annals, 7: 195-245.

Martin, R., \& Sunley, P. 2006. Path dependence and regional economic evolution. Journal of Economic Geography, 6(4): 395-437.

McVey, R. T. 1992. Southeast Asian Capitalists. Cornell: SEAP Publications.

Meyer, K. E. 2001. Institutions, transaction costs, and entry mode choice in Eastern Europe. Journal of international business studies, 32(2): 357-367.

Meyer, K. E., Mudambi, R., \& Narula, R. (2011). Multinational enterprises and local contexts: The opportunities and challenges of multiple embeddedness. Journal of management studies, $48(2), 235-252$.

Meyer, K. E., \& Sinani, E. 2009. When and where does foreign direct investment generate positive spillovers? A meta-analysis. Journal of international business studies, 40(7): 10751094.

Michalopoulos, S., \& Papaioannou, E. 2020. Historical legacies and African development. Journal of Economic Literature, 58(1): 53-128.

Morck, R., Wolfenzon, D., \& Yeung, B. 2005. Corporate governance, economic entrenchment, and growth. Journal of economic literature, 43(3): 655-720.

Mudambi, R. 2018. Knowledge-intensive intangibles, spatial transaction costs, and the rise of populism. Journal of International Business Policy, 1(1-2): 44-52.

Musacchio, A. \& Lazzarini, S. 2014. Reinventing State Capitalism: Leviathan in Business, Brazil and Beyond. 1st ed. Cambridge, Mass.: Harvard University Press.

Narine, S. 2012. ASEAN and the question of sovereignty: The persistence of non-intervention in the Asia-Pacific. In Beeson M., \& Stubbs, R. (Eds.), Routledge Handbook of Asian Regionalism: $155-165$

Nef, J. 2000. The political economy of inter-American relations: a structural and historical overview. In Stubbs, R, \& Geoffrey, R. D. (Eds.), Political economy and the changing global order. Toronto, Ontario, Canada: Oxford University Press.

North, D. C. (1990) Institutions, institutional change and economic performance, Cambridge: Cambridge University Press.

Onis, Z. 1991. The Logic of the Developmental State, Comparative Politics, 24(1):109-126. 
Peña-Vinces, J., Sanchez-Ancochea, D., Guillen, J., \& Aguado, L. 2020., Scientific Capacity and Industrial Development as Locomotors of International Competitiveness in Latin America. Technological and Economic Development of the Economy. 25 (2): 300-321, Available at SSRN: https://ssrn.com/abstract=3566980.

Phan, P. 2019. International politics and management research: a glaring white space calling out to be filled. Academy of Management Perspectives 33(1): 1-2.

Ramamurti, R., \& Singh, J. V. (Eds.). 2009. Emerging multinationals in emerging markets. Cambridge University Press.

Rauch, J. E., \& Trindade, V. 2002. Ethnic Chinese networks in international trade. Review of Economics and Statistics, 84(1): 116-130.

Rodrik, D. 2020. Putting Global Governance in its Place. The World Bank Research Observer, $35: 1-18$.

Rosenbusch, N., Gusenbauer, M., Hatak, I., Fink, M., \& Meyer, K. E. (2019). Innovation offshoring, institutional context and innovation performance: A meta-analysis. Journal of management studies, 56(1): 203-233.

Schneider, B. R. 2013. Hierarchical Capitalism in Latin America. Cambridge University Press.

Schneider, B. R. 2009. A comparative political economy of diversified business groups, or how states organize big business. Review of International Political Economy, 16(2): 178-201.

Schneider, B. R. 2004. Business politics and the state in twentieth-century Latin America. Cambridge University Press.

Sell, S. K. 2010. The rise and rule of a trade-based strategy: Historical institutionalism and the international regulation of intellectual property. Review of International Political Economy, 17(4): 762-790.

Shapiro, D., Hobdari, B., \& Oh. C.H. 2018. Natural resources, multinational enterprises and sustainable development. Journal of World Business, 53(1): 1-14.

Simsek, Z., Fox, B. C., \& Heavey, C. 2015. What's past is prologue: A framework, review, and future directions for organizational research on imprinting. Journal of Management, 41(1): 288317.

Skidmore, T. 1989, The Politics of Military Rule in Brazil, 1965-85. Oxford: Oxford University Press.

Stal, E., \& Cuervo-Cazurra, A. 2011. The Investment Development Path and FDI From Developing Countries: The Role of Pro-Market Reforms and Institutional Voids, Latin American Business Review, 12(3): 209-231. 
Stoian, C. 2013. Extending Dunning's Investment Development Path: The role of home country institutional determinants in explaining outward foreign direct investment. International Business Review 22(3): 615-637.

Stopford, J. M., Strange, S., \& Henley, J. S. 1991. Rival states, rival firms: Competition for world market shares Cambridge University Press.

Strachan, H. W. (1976). Family and other business groups in economic development: The case of Nicaragua. Praeger Publishers.

Strange, S. 1994|2015. States and Markets. Bloomsbury Publishing.

Stubbs, R. 2017. Rethinking Asia's economic miracle: The political economy of war, prosperity and crisis. Macmillan International Higher Education.

Stubbs, R. 1999. War and economic development: Export-oriented industrialization in East and Southeast Asia. Comparative Politics: 337-355.

Stubbs, R. (1994). 'The political economy of the Asia-Pacific region'. In Political Economy and the Changing Global Order Eds Stubbs, R \& Underhill G.Toronto: Macmillan \& Stewart: pp366-77.

Svejnar, J. 2002. Transition economies: Performance and challenges. Journal of Economic Perspectives, 16(1): 3-28.

Tan, D., \& Meyer, K. E. 2010. Business groups' outward FDI: A managerial resources perspective. Journal of International Management, 16(2): 154-164.

Teece, D. J. 2007. Explicating dynamic capabilities: the nature and micro-foundations of (sustainable) enterprise performance. Strategic management journal, 28(13): 1319-1350.

Venables, A. 2016. Using Natural Resources for Development: Why Has It Proven So Difficult? The Journal of Economic Perspectives, 30(1): 161-183.

UNCTAD. 2020 world investment report, annex table 20 the top 100 non-financial MNEs from developing and transition economies ranked by foreign assets.

https://unctad.org/en/Pages/DIAE/World\%20Investment\%20Report/Annex-Tables.aspx accessed September 28, 2020.

Vassolo, R. S., De Castro, J. O., \& Gomez-Mejia, L. R. (2011). Managing in Latin America: Common issues and a research agenda. Academy of Management Perspectives, 25(4), 22-36.

Wang, W. \& Ma, H. 2018. Export strategy, export intensity and learning: Integrating the resource perspective and institutional perspective, Journal of World Business, 53(4): 581-92. 
Weng, D. and Peng, M. 2018. Home bitter home: How labor protection influences firm offshoring, Journal of World Business, 53(5): 632-640

Witt, M. A., \& Jackson, G. 2016. Varieties of capitalism and institutional comparative advantage: A test and reinterpretation. Journal of International Business Studies, 47(7): 778806.

Witt, M.A., Kabbach de Castro. L.R., Amaeshi, K., Mahroum, S., Bohle D., \& Saez,L. 2018. Mapping the business systems of 61 major economies: a taxonomy and implications for varieties of capitalism and business systems research, Socio-Economic Review, 16(1): 5-38

Yiu, D. W., Lu, Y., Bruton, G. D., \& Hoskisson, R. E. 2007. Business groups: An integrated model to focus future research. Journal of Management Studies, 44(8): 1551-1579. 
Table 1: World Bank Enterprise Survey Sample Countries

\begin{tabular}{|c|c|c|c|c|c|c|c|}
\hline \multicolumn{2}{|c|}{ Southeast Asia } & \multicolumn{2}{|c|}{ Eastern Europe } & \multicolumn{2}{|c|}{ Africa } & \multicolumn{2}{|c|}{ Latin America } \\
\hline Country & Freq. & Country & Freq. & Country & Freq. & Country & Freq. \\
\hline Indonesia & 2764 & $\begin{array}{l}\text { Czech } \\
\text { Renublic }\end{array}$ & 504 & Morocco & 407 & Chile & 2050 \\
\hline Malaysia & 1,000 & Estonia & 546 & Nigeria & 4,567 & Argentina & 2,117 \\
\hline Philippines & 2,661 & Hungary & 601 & Tunisia & 592 & Venezuela & 820 \\
\hline Thailand & 1,000 & Latvia & 607 & Angola & 785 & Peru & 1,632 \\
\hline & & Lithuania & 546 & Cameroon & 363 & Brazil & 1,802 \\
\hline & & Poland & 997 & DR Congo & 1,228 & Colombia & 1,942 \\
\hline & & Slovak & 543 & Egypt & 2,897 & Mexico & 2960 \\
\hline & & Slovenia & 546 & Ethiopia & 1,492 & & \\
\hline & & Bulgaria & 1,596 & Ghana & 1,214 & & \\
\hline & & Georgia & 733 & Kenya & 1,438 & & \\
\hline & & Romania & 1,081 & Rwanda & 453 & & \\
\hline & & Ukraine & 1,853 & Senegal & 1,107 & & \\
\hline & & Belarus & 633 & Sudan & 662 & & \\
\hline & & Russia & 5,224 & Botswana & 610 & & \\
\hline & & Azerbaijan & 770 & Tanzania & 1,232 & & \\
\hline & & & & Uganda & 1,325 & & \\
\hline & & & & Namibia & 909 & & \\
\hline & & & & South & & & \\
\hline Total & 7.425 & Total & 16.780 & $\begin{array}{l}\text { Africa } \\
\text { Total }\end{array}$ & $\begin{array}{l}937 \\
22218\end{array}$ & Total & 13323 \\
\hline & & & & & & 10tal & 15,323 \\
\hline
\end{tabular}




\begin{tabular}{|l|l|l|}
\hline \multicolumn{2}{|c|}{ Table 2: Definitions and Sources of Variables } \\
\hline Variable & Definition & Source \\
\hline Export Intensity & Sales exported directly as percentage of total sales. & WBES \\
Firm Age & Year firm began operation to year of survey conducted & WBES \\
Firm Size (Log) & Log of number of permanent workers & WBES \\
GAF & Dummy indicating whether firms being part of larger enterprise (group affiliate) & WBES \\
Resource as \% of GDP & Total natural resources rents (\% of GDP) & World Development Indicator \\
Government efficiency & Perception of Quality of public service, policy formulation and implementation & World Governance Indicator \\
Corruption control & Perceptions of the extent to public power is exercised for private gain & World Governance Indicator \\
\hline
\end{tabular}

Table 3: Descriptive Statistics

\begin{tabular}{|c|c|c|c|c|c|c|c|c|c|c|c|c|}
\hline Variable & Mean & Std. Dev. & Min & Max & $\begin{array}{c}\text { Export } \\
\text { Intensity }\end{array}$ & Firm Age & $\begin{array}{c}\text { Firm Size } \\
(\log )\end{array}$ & $\begin{array}{l}\text { Resource as } \\
\% \text { of GDP }\end{array}$ & GAF & $\begin{array}{c}\text { Latin } \\
\text { America } \\
\text { dummy }\end{array}$ & $\begin{array}{c}\text { Government } \\
\text { efficiency }\end{array}$ & $\begin{array}{c}\text { Corruption } \\
\text { control }\end{array}$ \\
\hline Export Intensity & 10.680 & 25.475 & 0 & 100 & 1 & & & & & & & \\
\hline Firm Age & 2.741 & 0.766 & 0 & 5.278 & $0.0409 *$ & 1 & & & & & & \\
\hline Firm Size (Log) & 3.918 & 1.243 & 2.302 & 9.952 & $0.3141^{*}$ & $0.2127 *$ & 1 & & & & & \\
\hline Resource as $\%$ of GDP & 6.137 & 6.349 & 0.0015 & 43.795 & $-0.1310^{*}$ & $-0.1000 *$ & $-0.0826^{*}$ & 1 & & & & \\
\hline GAF & 0.176 & 0.381 & 0 & 1 & $0.0925^{*}$ & $0.0772 *$ & $0.2312 *$ & $-0.0463 *$ & 1 & & & \\
\hline Latin America dummy & 0.178 & 0.383 & 0 & 1 & $-0.0554 *$ & $0.1560 *$ & $-0.0169^{*}$ & $0.1787^{*}$ & $-0.0233^{*}$ & 1 & & \\
\hline Government efficiency & -0.188 & 0.529 & -1.74 & 1.27 & $0.0499 *$ & $0.1250 *$ & $0.0353 *$ & $-0.1986^{*}$ & $0.0207^{*}$ & $0.2944^{*}$ & 1 & \\
\hline Corruption control & -0.416 & 0.559 & -1.53 & 1.5 & $0.0243 *$ & $0.1123^{*}$ & 0.0006 & $-0.0405^{*}$ & $0.0346^{*}$ & $0.3980 *$ & $0.8753 *$ & 1 \\
\hline
\end{tabular}




\begin{tabular}{|c|c|c|c|}
\hline \multicolumn{4}{|c|}{ Table 4: Export Equation for WBES Sample } \\
\hline Variable & \multicolumn{3}{|c|}{$\begin{array}{c}\text { Export Intensity as Dependent } \\
\text { Variable }\end{array}$} \\
\hline \multirow{3}{*}{ Firm Age } & Model 1 & Model 2 & Model 3 \\
\hline & $-0.765 * *$ & $-0.689 * *$ & $-0.675^{* *}$ \\
\hline & $(0.174)$ & $(0.175)$ & $(0.175)$ \\
\hline \multirow[t]{2}{*}{ Firm Size (Log) } & $5.824 * *$ & $5.809 * *$ & $5.816^{* *}$ \\
\hline & $(0.112)$ & $(0.112)$ & $(0.112)$ \\
\hline \multirow[t]{2}{*}{ Resource as \% of GDP } & $-0.223 * *$ & $-0.239 * *$ & $-0.237 * *$ \\
\hline & $(0.026)$ & $(0.026)$ & $(0.026)$ \\
\hline \multirow[t]{2}{*}{ GAF Dummy } & $1.060 * *$ & $1.067 * *$ & $1.677 * *$ \\
\hline & $(0.354)$ & $(0.354)$ & $(0.382)$ \\
\hline \multirow[t]{2}{*}{ Government efficiency } & $4.689 * *$ & $3.593 * *$ & $3.612 * *$ \\
\hline & $(0.660)$ & $(0.723)$ & $(0.723)$ \\
\hline \multirow[t]{2}{*}{ Corruption control } & $-1.638 * *$ & -0.405 & -0.414 \\
\hline & $(0.596)$ & $(0.683)$ & $(0.683)$ \\
\hline \multirow[t]{2}{*}{ Latin America } & & $-2.062 * *$ & $-1.459^{*}$ \\
\hline & & $(0.558)$ & $(0.576)$ \\
\hline \multirow[t]{2}{*}{ GAF* Latin America } & & & $-4.037 * *$ \\
\hline & & & $(0.946)$ \\
\hline \multirow[t]{2}{*}{ Constant } & $-11.548 * *$ & $-11.051 * *$ & $-11.472 * *$ \\
\hline & $(1.729)$ & $(1.734)$ & $(1.737)$ \\
\hline Adjusted R2 & 0.135 & 0.135 & 0.135 \\
\hline $\mathrm{F}$ & 167.951 & 163.037 & 158.596 \\
\hline $\mathrm{N}$ & 32,196 & 32,196 & 32,196 \\
\hline
\end{tabular}

${ }^{*} \mathrm{p}<0.10, * * \mathrm{p}<0.05, * * * \mathrm{p}<0.01$ 


\section{Appendix}

\begin{tabular}{|c|c|c|c|}
\hline \multicolumn{4}{|c|}{$\begin{array}{l}\text { Table A1: Export Equation for WBES Sample, with Mexico } \\
\text { included in LA dummy }\end{array}$} \\
\hline \multirow[t]{2}{*}{ Variable } & \multicolumn{3}{|c|}{$\begin{array}{l}\text { Export Intensity as Dependent } \\
\text { Variable } \\
\end{array}$} \\
\hline & Model 1 & Model 2 & Model 3 \\
\hline \multirow[t]{2}{*}{ Firm Age } & $-0.765 * *$ & $-0.524 * *$ & $-0.508 * *$ \\
\hline & $(0.174)$ & $(0.175)$ & $(0.175)$ \\
\hline \multirow[t]{2}{*}{ Firm Size (Log) } & $5.824 * *$ & $5.790 * *$ & $5.802 * *$ \\
\hline & $(0.112)$ & $(0.112)$ & $(0.112)$ \\
\hline \multirow[t]{2}{*}{ Resource as \% of GDP } & $-0.223 * *$ & $-0.330 * *$ & $-0.329 * *$ \\
\hline & $(0.026)$ & $(0.027)$ & $(0.027)$ \\
\hline \multirow[t]{2}{*}{ GAF Dummy } & $1.060 * *$ & $1.053 * *$ & $1.934 * *$ \\
\hline & $(0.354)$ & $(0.353)$ & $(0.391)$ \\
\hline \multirow[t]{2}{*}{ Government efficiency } & $4.689 * *$ & $2.401 * *$ & $2.415 * *$ \\
\hline & $(0.660)$ & $(0.679)$ & $(0.679)$ \\
\hline \multirow[t]{2}{*}{ Corruption control } & $-1.638 * *$ & 1.120 & 1.110 \\
\hline & $(0.596)$ & $(0.629)$ & $(0.628)$ \\
\hline \multirow[t]{2}{*}{ Latin America with Mexico } & & $-8.884 * *$ & $-8.251 * *$ \\
\hline & & $(0.660)$ & $(0.671)$ \\
\hline \multirow{2}{*}{$\begin{array}{l}\text { GAF* Latin America with } \\
\text { Mexico }\end{array}$} & & & $-4.467 * *$ \\
\hline & & & $(0.850)$ \\
\hline \multirow[t]{2}{*}{ Constant } & $-11.548 * *$ & $-10.726^{* *}$ & $-11.320 * *$ \\
\hline & $(1.729)$ & $(1.726)$ & $(1.729)$ \\
\hline Adjusted R2 & 0.135 & 0.139 & 0.140 \\
\hline $\mathrm{F}$ & 167.951 & 169.283 & 164.991 \\
\hline $\mathrm{N}$ & 32,196 & 32,196 & 32,196 \\
\hline
\end{tabular}

$* \mathrm{p}<0.10, * * \mathrm{p}<0.05, * * * \mathrm{p}<0.01$ 


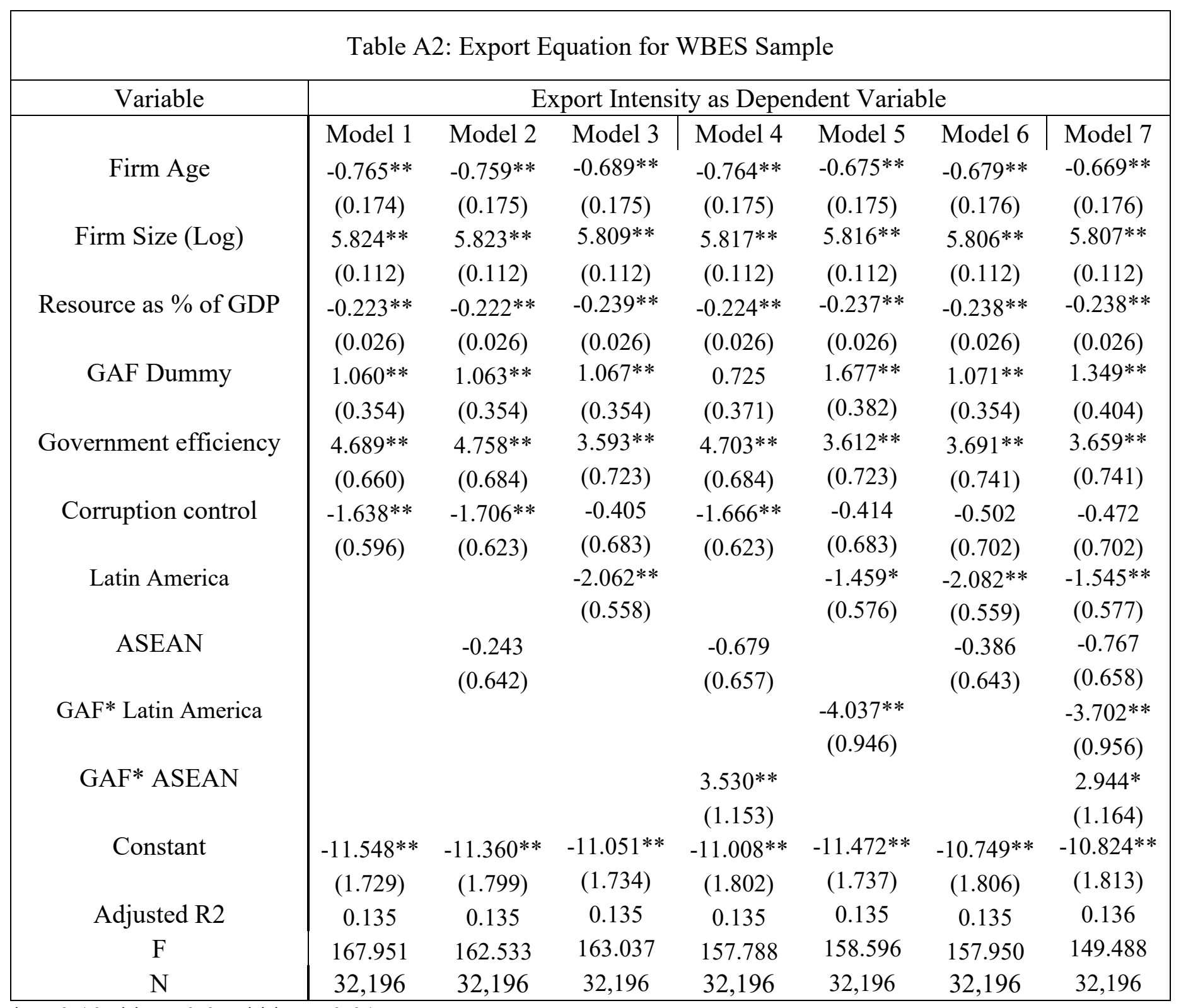

${ }^{*} \mathrm{p}<0.10, * * \mathrm{p}<0.05, * * * \mathrm{p}<0.01$ 